\title{
PROACTIVE CONTRACTING IN FINNISH PPP PROJECTS
}

\author{
Antti TIEVA $1 \bowtie$ and Juha-Matti JUNNONEN 2 \\ 1 CEM Facility Services Research, Department of Civil and Environmental Engineering, Hel- \\ sinki University of Technology, P.O. Box 3300, FIN-02015 HUT, Finland \\ E-mail: antti.tieva@tkk.fi; tel: +358505359281 \\ 2 CEM Facility Services Research, Department of Civil and Environmental Engineering, Hel- \\ sinki University of Technology, P.O. Box 3300, FIN-02015 HUT, Finland \\ E-mail: juha-matti.junnonen@tkk.fi
}

Received 23 February 2009; accepted 8 May 2009

\begin{abstract}
Public-private-partnership projects are long term, complex and very challenging contractual arrangements and relationships. They bring new roles for public sector and also for private sector in terms of construction and services. This paper will go through some features of the Finnish PPPs. Proactive law focuses in practical views as regards contract law and contractual issues. The main target is to prevent problems instead of confronting them. This paper will clarify what proactive law is about in terms of contract law and contracting especially in PPPs. For instance, 20-40 years' partnership relation with PPPs brings up also dozens of different risks into the picture. This paper will discuss the risks and risk management in terms of proactive law and after that, focus on PPPs in Finland.
\end{abstract}

KEYWORDS: Proactive contracting; Risk management; Public-private partnership

\section{INTRODUCTION}

There is a worldwide trend toward publicprivate partnerships (PPPs) in public infrastructure development. PPP projects have caused much debate also in Finland during the past few years. One of the reasons for this is that PPPs are a new kind of model for producing public sector construction services and also other services related to them. PPP projects change the traditional roles of the public sector bodies and private sector companies (cf. Froud, 2003). The public sector becomes a client and the private sector becomes a service provider with a large responsibility.

PPP projects are long-term contractual arrangements in which the contract period is usually 10-40 years. This long contract period brings up certain issues, for example, in terms of proactive law and risk management (cf. Shaoul, 2005). In Finland, PPP projects are established, for example, in building motorways, schools, sport and swimming halls, and waste water treatment facilities.

Many types of PPP models have been adopted. The term PPP covers several more specified models which all are, in one way or another, partnerships between the public and private sector. These models are, for example: DBFO, BOO, BOT, BOOT, BTO, BRT, and BLT (e.g. Gallimore et al., 1997). These abbreviations consist of words and word parts like design, build, finance, own, operate, lease, rehabilitate, rent, and transfer. The common 
denominator of all these models is that the private sector partners have the responsibility for at least designing, building, and operating a project-facility. All these models are in common use and each project form has its individual character for instance, regarding to proactive law and risk management.

The new roles mean that private sector partners (often, a separate project company) bind themselves to the production of different kinds of services, for example, in addition to building a facility or a motorway. These services can be, for instance, maintenance, real estate services, cleaning, guarding, catering etc. (cf. Grimsey and Lewis, 2005). It is also possible that private sector partners commit to arranging the financing for the project. See Figure 1.

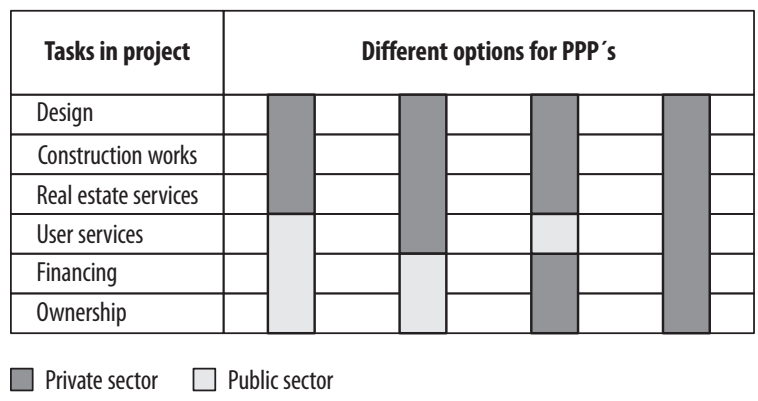

Figure 1. Different options for PPPs

The research questions in this article are: what is proactive contracting especially in the relation of risks and risk management and how does proactive contracting become apparent in Finnish PPP projects?

\section{PAYMENT MECHANISM IN PPP PROJECTS}

A public-sector partner binds itself to longterm payment mechanism according to which it pays, for example, a monthly service fee to the private-sector partner. In this way, the public-sector partner avoids large non-recurring investments and can arrange its own budget policy from a new starting point (cf. Shaoul, 2005). These new roles are essential concerning this new public and private sectors' partnerships where, in the spirit of partnership, both parties try to achieve long-term contractual arrangements in which both parties win (cf. Zhang, 2005).

The public sector partner hopes that PPP procurement can provide a variety of net benefits for the society, including enhanced government capacity, innovation in delivering public services, reduction in the cost and time of project implementation, and transfer of major risks to the private sector, in order to secure value for money for taxpayers (cf. Li et al., 2005a). In addition, the payment mechanism mentioned above is part of the public sector bodies' objectives. With the new payment mechanism, a public-sector partner can plan its budget policy from a new starting point. This payment mechanism means that service fees are divided for the whole contract period. By avoiding large, non-recurring investments, for example, in a case of building a school, the city can use the money saved for other purposes.

In addition to the advantageous payment mechanism, other benefits for the public-sector partner can be found. These benefits, in the case of Finnish facility projects, are fast building time of the facility, the private-sector partner taking responsibility for the facility and services during the contract period, and a small risk for the client because the service fee is paid only when the services are produced in the correct and agreed way (Nykänen and Sal$\mathrm{mi}, 2002)$. If services do not meet the demands which are mentioned in the service contract, the public-sector partner has a right to a reduced service fee. That is why a private-sector partner tries to avoid such reductions as they affect the project's profitability (Lahdenperä and Rintala, 2003).

Additionally, after the selection, the private-sector partner has an economical incen- 
tive to start producing services, for instance, in a facility as soon as possible because the phase after the construction the facility (service period) also marks the starting point for paying the obligatory service fees. This also means that the construction phase shortens.

Service fees are the only real significant source of income from PPP projects for the private-sector partner. Therefore, every possible thing has to be taken into account in the preparation phase before starting the implementation of the project. If everything goes as planned, the private-sector partner receives service fees throughout the project (cf. Zhang, 2005). As a whole, the partnership mindset and the idea that both partners (public and private) win are the main principles in PPP projects. In practice, the public sector seeks efficiency in construction and services as well as economical savings. For the private sector, a successful long-term contractual relation-ship brings profit throughout the contract period and enables the sector to develop innovations in services in a long-term perspective.

Essential to project success is good and careful planning and finding and connecting good co-operative partners. In addition, identifying and handling different risks is essential due to the long contract period. Therefore, it is vital that the contract elements are included in the contract that prevents disputes between partners and provides the extension of the contract.

\section{PROACTIVE CONTRACTING}

\subsection{General features of proactive contracting}

Conceptions concerning legal issues, disputes, and the ways to solve them traditionally emphasize the courts' and other institutions' position and power. Courts and other institutions consider legal issues and disputes subsequently. This kind of approach is very common concerning legal interpretations. In Finland, the Supreme Court's precedents have an indisputable and strong influence on legal thinking. This means that this influence has significance in various parts of the Finnish society. However, during the past few years, proactive law has got an important role especially in contract law and contracting also in Finland (e.g. Sorsa, 2009; Pohjonen, 2002; Pohjonen, 2005).

Practising proactive contracting means more planning of legal relations so that the objective is to prevent complicated future situations and avoid problems. The aim is not to plan legal relations in the context of dispute resolution. The traditional way to focus on dispute resolution with different laws and regulations is seen as a very static model. Because of this, there is a need to develop proactive means of resolution which could rely on more flexible tools (Holming, 2002).

There are two significant differences between proactive legal practice and traditional legal practice. The first is that proactive legal practice deals prospectively with fact patterns that may arise in the future (hot facts) while traditional legal practice deals retrospectively with established facts concerning events that have occurred in the past (cold facts). The second difference is that in traditional legal practice, the ultimate decision maker is usually a third party, such as a judge or arbitrator, while in proactive legal practice, the ultimate decision maker is the client, acting on the advice of an attorney. The job of the traditional lawyer is to act as a historian, interpreting past events in a light that is most favourable to the client. The job of the proactive lawyer is to help the client to shape future events so that the facts will reflect favourably on the client (Gruner, 1998).

Proactive contracting can also been seen in the context of flexibility. In that sense parties can seek flexibility by creating responsive contract mechanisms in to long-term business contracts. These mechanisms can deal for example with co-operational procedures, chang- 
ing circumstances and alternative dispute resolution. With these mechanisms parties can respond to changing circumstances and situations and in best case continue their contractual relationship. This goal can be set for example in partnerships (Tieva, 2008).

Proactive contracting invites and gathers different professions together to co-operate in a new way. Complicated technical, financial and legal issues in PPP contracts mean that according to the principles of proactive contracting, all the people who work in these areas in the companies involved have to cooperate closely and intensively. One essential feature of co-operation and proactive contracting is the skill of communicating and active participating. Instead of assuming and making interpretations, one has to try to pose clarifying and specifying questions (Rudanko, 2002). This kind of unprejudiced working method in the preparation phase of a contract makes it possible to prevent potential contractual problems and achieve the set goals. Making this happen requires developed company-specific action models and creative contractual mechanisms to prevent and manage risks.

\subsection{Risks and risk management in a proactive light}

Essential features of proactive contracting on contract management are also risks and risk management. Therefore, contract preparation and negotiations are salient poles. Risk and uncertainty describe the possibility of different potential outcomes. Some systems feature inherent randomness, such as games of chance. In business, the risks and uncertainties reflect unknowns and variability in nature, materials, and human systems (Schuyler, 2001). Risks can be divided into harmful and beneficial risks. A harmful risk can be, for example, a situation an employee does not want to tumble into (for example, an accident at work). A beneficial risk can be seen as a course of events in which some positive effects can become mate- rialized, for instance, to a person but there are still some uncertainties and questions concerning them (Määttä, 1999).

In the context of contract law and contract management, risk as a concept can be determined as well. One definition emphasizes comprehensively proactive views on risks. Firstly, a distribution between danger and risk has to be made. The conclusion is that dangers that can be avoided are risks but dangers that cannot be avoided remain true dangers. With this distribution, the significance of the extent to which dangers are avoided should also be noted. In this sense, all dangers are risks when their consequences can be minimized. Secondly, risks and liabilities should also be distinguished (Keskitalo, 2000).

Traditionally, risks have been defined and allocated retrospectively after the conclusion of a contract and the realisation of risks. That is why risks are often identified with liabilities. When the proactive nature of risks is abandoned, the fact that rationalising risks and internalising them to the decision making process is a tool for planning contracts is denied. Therefore, risks should be handled prospectively and liabilities retrospectively. The concept of liability is linked equally to risks and dangers since liability as a term illustrates both the risks' and dangers' subsequent legal consequences. In terms of proactive law, risks and dangers are potential liabilities (Keskitalo, 2000).

Risk management is one of the key elements in proactive law, especially concerning contracts and contract law. Generally, risk management means developing company-specific measures and creating mechanisms which can manage estimated potential future risks that threaten companies. It also means corporate governance. In the best case, comprehensive risk management can help in reaching goals, enhance planning, create satisfaction for interest groups, create protection against uninsurable risks and balance profits to several years (Fiilin, 2000). 
Contractual risk management forms only one part of the companies' legal risk management and, in this way, it is part of companies' comprehensive general risk management. The goals of contractual risk management do not restrict the management of legal risks in contracting. Contractual risk management also covers other risks in business by using methods of contractual planning and management. This requires broad, planned and continuing communication inside companies between business executives, contracting people and risk management people (Keskitalo, 2002).

\section{PROACTIVE CONTRACTING IN FINNISH PPP PROJECTS}

\subsection{Questions concerning contract preparation}

Each PPP project consists of several different contracts. These contracts cover, for example, construction, financing, and different kinds of services (cf. Zhang, 2005). PPP projects are long-term and very complex contractual arrangements which require careful and time-consuming preparation and negotiations. A great amount of technical, financial and legal questions and details need time in order to be handled carefully. The case is the same with risks and risk management. PPP projects contain many risks that have to be identified, processed, and allocated in a thorough manner (e.g. Li et al., 2005b). When a 10-40 year contractual relationships is in question, risks play a huge role. It is reasonable to handle all possible risks in a proactive way before concluding contracts.

Despite the increasing popularity of the use of PPP concept as a procurement strategy, there have been reported cases of problems associated with the initial stages of the process in terms of unduly high bidding costs and pre-contract time overruns, due mainly to the protracted nature of the negotiations (Ahadzi and Bowles, 2004). Public sector clients should be better able to establish effective risk allocation strategies and develop suitable allocation frameworks for PPP projects, with a view to achieving a more efficient process of contract negotiation ( $\mathrm{Li}$ et al., 2005b)

PPP projects contain several questions and issues that directly influence the success of projects. According to Li et al. (2005a), the three most important issues are: a strong and good private consortium, appropriate risk allocation, and an available financial market. As a general rule, risks should be borne by the party that is in the best position to assess and influence the probability and financial impact of its occurrence as well as to manage and bear the consequences of its materialisation (European International Contractors, 2003). In one Finnish PPP project, risk allocation has been carried out with a matrix which determines which risks are directed towards private-sector and the public-sector partner. Most of the identified risks concern operations and maintenance risks during the contract period. See Figure 2 (The city of Espoo, 2001).

\subsection{Changing circumstances during a contract period}

Regarding long-term contracts and business relationships, the relevance of different changing circumstances becomes stronger in terms of contract law. Generally, changing circumstances are related to anticipation. This way, the theme of changing circumstances is related to general and contractual risk management. Generally changing circumstances also cause problems in contractual relationships. It has been stated that the foreseeability of problems decreases as the duration of contractual relationship increases. Technically, the most difficult changing circumstances to solve are unforeseeable, fundamental, permanent, or long-term changes which significantly affect either the original cost structure or earnings (Kurkela, 2003). 


\begin{tabular}{|l|c|c|c|c|}
\hline \multicolumn{1}{|c|}{ Risks } & Project company & Subcontractor A & Subcontractor B & Client \\
\hline Construction engineering & & $X$ & & \\
\hline Information systems & & & $X$ & \\
\hline Energy & & & & $X$ \\
\hline Communication services & & & & \\
\hline Insurances & $X$ & & & \\
\hline Rents & $X$ & & & \\
\hline Real estate taxes & $X$ & $X$ & & \\
\hline General facility management & $X$ & & & \\
\hline
\end{tabular}

Figure 2. Parts of the risk allocation in the example case

Several legal effects are possible when a changing circumstance is powerful enough and other preconditions that have to be taken into account are fulfilled. This means that these preconditions are unforeseeable, blameless, and unbeatable. Naturally, one can try to prepare for changing circumstances with contract clauses when these clauses change the contract in an agreed way (Hemmo, 2003). When such clauses do not exist, studying this theme changes. It has been stated that when a changing circumstance relates to only one point in the contract so that certain obligations can not be executed, then the position of the rest of the obligations are evaluated. If it is reasonable to fulfil the other part of the contract, then the contract with this part stays in force. In this sense, it is a question of partial expiration (Hemmo, 2003).

It is also stated that businesses are sometimes forced to adjust for external facts such as official regulations and legislation. These reforms are not in the hands of the contract parties. Especially, changes in the established practises might influence the execution of the contract in a way that cannot be foreseen (Hemmo, 2003). This is essential in long-term contractual relationships because it is possible that during a contract period of several years, new official regulations and laws come into force. That is why it is rational for the contract parties to act in a proactive way and to draft contract clauses concerning these matters.
In several ways, hardship and renegotiations are connected to the theme of changing circumstances. Both have found their place in the sweep of international contract law (e.g. Mähönen, 2000). In the context of hardship and renegotiations, certain contractual questions are emphasized. Particularly, in international business environments and contracts both of these often exist. Lately, they have been appearing more and more in Finnish business contracts and also in PPP contracts.

As regards hardships, it is a question of contract clauses that retrospectively repair the effects of changed circumstances (e.g. Unidroit Principles of International Commercial Contracts, 1994). With contract clauses, parties try to define, for example, performance excuses that can free them from liabilities concerning payment in kind and damages. With contract clauses, it is also possible to govern the extension of performance time and the right of withdrawal. Furthermore, generally in the context of hardship, in contract clauses it is often defined as an obligation to start negotiating of a need to modify contract (Hemmo, 2003). This means the contractual term renegotiations (cf. Bolton and Dewatripont, 2005; Klein, 1996; Klein, 1988).

Force majeure is also associated with the theme of changing circumstances and it often exists in business contracts. Also for PPP projects, it is rational and wise to draft de- 
tailed contract clauses covering all of these contractual mechanisms: hardship, renegotiations, and force majeure. This is part of the proactive mindset and actions which render the contract and the whole business relationship more flexible.

\subsection{Risk management tools}

In Finnish PPP projects and their contractual arrangements, tailored contract clauses, insurances, securities, and guarantees have been used as tools for managing and allocating risks. It has been perceived that the most problematic situations are those in which risks are not individualised. In addition, problems arise when a risk is individualised but risk-bearing partner is not agreed on. Risks are usually divided between the partners by contract clauses and often, the parties have agreed which one bears certain risks and which one is obliged to obtain insurances. Occasionally, the partner who bears a risk is not the same than the partner who gets the insurance for the risk. Some of the risks are covered through traditional insurances. In case of a facility, a fire insurance is usually mandatory. Most of the other risks, but not all, can be covered by special insurances. For instance, in case of political risks, there are possibilities to obtain governmental guarantees and there can also be other special arrangements for covering other types of risks (Kurkela, 2003).

Once the risk allocation is agreed and defined in the contract, both parties (private and public sectors) can move to the risk treatment stage in contract management. In order to facilitate this outcome, it is important to understand how the public and private sector parties (with experience in PPP) perceive risk allocation, and what allocation preferences they exhibit. This in turn requires the identification of particular risks (and groupings of risks) for PPP projects (Li et al., 2005a). Contracts are intended to remake the future in a way that is more controllable, for instance, by effectively insuring against faults with the operation of the building or its associated services (Froud, 2003).

As an example, I shall use one Finnish PPP project to clarify the processes of proactive law and risk management. In the project, a project company carries out the objects' construction and services (real estate, catering, guarding, and tele-communications) for 25 years. The objects are a school and a swimming a sport hall. The service contract states that the private-sector partner is obliged to ensure that all buildings have fire insurances for the whole contract period. In addition, the private-sector partner ensures that it has a liability insurance covering the amount of the tender it has made earlier. Additionally, the private-sector partner has to have a loss-of-profits insurance that covers the losses (profits per a year) that have been caused by an interruption of business or a delay. Furthermore, the project company has to obtain all insurances that are required by Finnish legislation (The city of Espoo, 2001).

The same contract discusses risks that are uninsurable. The contract states that if any private-sector partner's risk which cannot be covered by insurances materialises during the contract period, the private sector partner has to inform the public-sector partner of this immediately and the parties have to negotiate the management of this risk. If the parties do not find a solution to the situation, the privatesector partner's monthly service fees will be reduced (The city of Espoo, 2001).

In terms of proactive law and risk management, other contractual mechanisms can also be found. Essential features of these cases are breaches of contract and the legal consequences arising from them. In the construction phase, if the buildings are not ready on schedule, the private-sector partner is obliged to pay liquidated damages and compensation for the direct damages to the public-sector partner. 
During the operation period, if the private-sector partner breaches the contract, the publicsector partner has the right of subrogation in terms of providing the services determined in the contract. In this situation, the private-sector partner also has to pay compensation for the costs of the actions that the public-sector partner has to take because of the subrogation. Moreover, the service contract contains several provisions on resigning the contract because of breaches of contract (The city of Espoo, 2001).

\section{CONCLUSION}

PPP projects have lately become a popular operation model in public infrastructure development all over the world. Long-term contractual arrangements with PPPs change the traditional roles of the public and private sectors. Public sector bodies become clients and private sector bodies become service providers with a large responsibility of the project in question. PPP projects offer different kinds of benefits to both public and private parties. Both partnership parties also have different kinds of goals; however, the common goal is that both parties win.

As the results in the text show, proactive law becomes relevant in contract law and contracting. Practising proactive contracting requires more planning of legal relations. The goal is to prevent difficult future situations and avoid problems. Proactive contracting emphasises contract preparation. That is why, for example, issues and questions concerning risks, risk management and creative contractual mechanisms play a significant role. In business relations, proactive contracting invites and gathers different professions to participate in a new type of co-operation. A common language has to be found, for example, between the people in companies with technical, financial, and legal backgrounds. In this way, it is possible to assess the possible risks and other critical contractual questions in the contract preparation phase.
A partnership mindset is essential in PPP projects. A client and a project company form the main contractual relationship in terms of PPP projects. In addition to this, for example, a project company has several contracts with subcontractors. These partnerships are complex contractual relationships in which trust plays a big role. Co-operation requires constant care in the form of communication and reciprocal trust to strengthen it. Trust is achieved by the companies and public sector representatives binding themselves to shared goals. Furthermore, once strong trust has been built and established, firms may enjoy lower costs than those without such trust. In the business context, trust seems to be based partly on economic calculations and partly on the trusting party's basic values as a human being.

Each PPP project consists of several different contracts, so that they are actually a bundle of contracts. These contracts cover, for example, construction, financing, and services. PPP projects are long-term and very complex contractual arrangements which require careful and time-consuming preparation and negotiations. Dozens of different risks exist as well. As regards risks with PPP projects, the proactive way is the only reasonable way to handle and allocate them. This requires investments from the parties.

As the results in the text show, changing circumstances play a significant role in long-term contracts and, for instance, in PPP projects in terms of contract law. It is sensible for the parties to prepare for changing circumstances. This requires proactive mindset and actions. In practise, this means that parties have to create flexible contractual mechanisms for contracts so that they can respond to possible changing circumstances in the future. These mechanisms can be, e.g. clauses concerning changes in official regulations and legislation, hardship, renegotiations, and force majeure. 
As the results in the text show, in Finnish PPP projects and their contractual arrangements, tailored contract clauses, insurances, securities, and guarantees have been used as tools for managing and allocating risks. It has also been noted that the most problematic situations arise when risks are not individualised. Problems also occur when a risk is individualised but the risk-bearing party is not determined. Proactive law and risk management play significant roles in PPP projects. Moreover, tailored contract clauses and mechanisms also have a great significance.

\section{REFERENCES}

Ahadzi, M. and Bowles, G. (2004) Public-private partnerships and contract negotiations: an empirical study, Construction Management and Economics, 22(9), pp. 967-978.

Bolton, P. and Dewatripont, M. (2005) Contract theory. Cambrigde: The MIT Press.

European International Contractors (2003) EIC White Book on BOT/PPP. [Online] European International Contractors. Available at: http:// www.eicontractors.de/seiten/bookshop/eic white_book.pdf

Fiilin, P. (2000) Kohti kokonaisvaltaista riskienhallintaa [Towards comprehensive risk management]. Fakta 10/2000. Finland. (In Finnish)

Froud, J. (2003) The Private Finance Initiative: risk, uncertainty and the state, Accounting, Organizations and Society, 28(6), pp. 567-589.

Gallimore, P., Williams, W. and Woodward, D. (1997) Perceptions of risk in the Private Finance Initiative, Journal of Property Finance, 8(2), pp. 164-176.

Grimsey, D. and Lewis, M.K. (2005) Are Public Private Partnerships value for money?: Evaluating alternative approaches and comparing academic and practitioner views, Accounting Forum, 29(4), pp. 345-378.

Gruner, R. (1998) What is preventive law? [Online] Available at: www.cyberinstitute.com/preventivelaw/week1.htm.

Hemmo, M. (2003) Sopimusoikeus II [Contract law II]. Talentum, Finland. (In Finnish)

Holming, B. (2002) Ennakoiva näkökulma sopimusoikeudessa [Proactive perspective in contract law]. Vientijuridiikkaa 7/2002. Finland. (In Finnish)

Keskitalo, P. (2000) From assumptions to risk management. The Finnish Federation of Lawyers, Finland.

Keskitalo, P. (2002) Sopimuksellisen riskienhallinnan teoria ja sen toimintamallit. Teoksessa Ennakoiva sopiminen, liiketoimien suunnittelu, toteuttaminen ja riskienhallinta [The theory of contractual risk management and its policies. Proactive contracting, planning and realizing the business and risk management]. WSOY Lakitieto, Finland. (In Finnish)

Klein, B. (1996) Vertical integration as organizational ownership: the Fisher Body-General Motors relationship revisited. In: Masten, S.E. ed. Case studies in contracting and organization. New York: Oxford University Press.

Klein, B. (1988) Vertical integration as organizational ownership: the Fisher Body-General Motors relationship revisited, Journal of Law, Economics \& Organization, 4(1), pp. 199-213.

Kurkela, M. (2003) Kumppanuussopimukset elinkaarimallissa, rakentaminen, rahoittaminen ja palvelutuotanto [Partnership agreements in PPP projects, construction, financing and service production]. The Finnish Construction Industry, Finland. (In Finnish)

Lahdenperä, P. and Rintala, K. (2003) Ajatuksia elinkaarivastuuhankkeista. Brittiläisten tilapalveluhankintojen tarkastelua uuden suomalaisen käytännön kehittämiseksi [Thoughts of PPP projects. Studying procurements of British facility management to develop a new Finnish practise]. Technical Research Centre of Finland, Finland. (In Finnish)

Li, B., Akintoye, A., Edwards, P.J. and Hardcastle, C. (2005a) Critical success factors for PPP/PFI projects in the UK construction industry, Construction Management and Economics, 23(5), pp. 459-471.

Li, B., Akintoye, A., Edwards, P.J. and Hardcastle, C. (2005b) The allocation of risk in PPP/ PFI construction projects in the UK, International Journal of Project Management, 23(1), pp. 25-35.

Mähönen, J. (2000) Varallisuusoikeuden kantavat periaatteet [The main principles of property law]. Werner Söderström lakitieto, Finland. (In Finnish)

Määttä, K. (1999) Oikeustaloustieteen aakkoset [The alphabet of law and economics]. Helsinki Unversity, Finland. (In Finnish) 
Nykänen, V. and Salmi, J. (2002) Elinkaarivastuullinen palveleva rakentaminen [Life cycle, responsible construction]. The Finnish Construction Industry, Finland. (In Finnish)

Pohjonen, S. (ed.) (2002) Ennakoiva sopiminen. Liiketoimien suunnittelu, toteuttaminen ja riskien hallinta [Proactive contracting, planning and realizing the business and risk management]. WSOY Lakitieto, Finland. (In Finnish)

Pohjonen, S. (ed.) (2005) Ex ante - Ennakoiva oikeus [Ex ante - Proactive law]. Talentum, Finland. (In Finnish)

Rudanko, M. (2002) Ennakoiva näkökulma kauppaoikeudessa. Ennakoiva sopiminen, liiketoimien suunnittelu, toteuttaminen ja riskien hallinta [Proactive perspective in trade law [Proactive contracting, planning and realizing the business and risk management]. WSOY Lakitieto, Finland. (In Finnish)

Schuyler, J. (2001) Risk and decision analysis in projects. Project Management Institute. Upper Darby, PA.

Shaoul, J. (2005) A critical financial analysis of the Private Finance Initiative: selecting a financing method or allocating economic wealth? Critical Perspectives on Accounting, 16(4), pp. 441-471.

Sorsa, K. (2009) Elinkeinoelämä tarvitsee ennakoivaa sopimusosaamista [Business life needs proactive contractual skills]. 1/2009 Defensor Legis, Finland, pp. 128-151. (In Finnish)

The city of Espoo (2001) The Kaivomestari PPP project. The service contract. The city of Espoo, Finland.

Tieva, A. (2008) Reagoivan sopimuksen idea sopimusteknisenä lähtökohtana [The idea of responsive contract as a contractual starting point]. 3/2008 Lakimies, Finland, pp. 433-453. (In Finnish)

Unidroit Principles of International Commercial Contracts (1994) International Institute for the Unification of Private Law. Rome. 6.2.1-6.2.3.

Zhang, X. (2005) Critical success factors for publicprivate partnerships in infrastructure development, Journal of Construction Engineering and Management-ASCE, 131(1), pp. 3-14.

\section{SANTRAUKA}

\section{INICIATYVUS SUTARČIŲ SUDARYMAS SUOMIJOS VPP PROJEKTUOSE}

\section{Antti TIEVA, Juha-Matti JUNNONEN}

Viešojo ir privataus sektoriu partnerystès (VPP) projektai - tai ilgalaikiai, sudètingi ir itin daug pastangu reikalaujantys sutartiniai susitarimai ir santykiai. Ne tik viešajame, bet ir privačiajame sektoriuje jie sukuria naujus, su statyba ir paslaugomis susijusius, vaidmenis. Šiame darbe apžvelgiami kai kurie Suomijos VPP bruožai. Iniciatyvi teise glaudžiai susijusi su praktinėmis pažiūromis, sutarčiu teise ir pan. Pagrindinis tikslas - išvengti problemu užuot jas sprendus. Šiame darbe paaiškinama iniciatyvios teisès esmè sudarant sutartis, ypač VPP. Pavyzdžiui, kai VPP trunka 20-40 metu, susiduriama su daugybe įvairių rizikos rūšių. Todèl straipsnyje pirmiausia aptariamos rizikos rūšys ir rizikos valdymo būdai taikant iniciatyvią teisę, o po to - Suomijos VPP. 